\title{
IMPLEMENTASI KURIKULUM K13 DENGAN PENDEKATAN SAINTIFIK PADA PELAJARAN PAI DI SMP NEGERI I BEJI
}

\author{
Mukhamad Auliya Rahman', Istikomah ${ }^{2}$ \\ ${ }^{1}$ Program Studi Pendidikan Agama Islam, Fakultas Agama Islam Universitas Muhammadiyah \\ Sidoarjo, Indonesia . \\ ${ }^{2}$ Program Studi Pendidikan Agama Islam, Fakultas Agama Islam, Universitas Muhammadiyah \\ Sidoarjo, Indonesia.
}

mukhamadrahman913@gmail.com, Istikomah@umsida.ac.id

\begin{abstract}
Abstrak : Dalam proses pembelajaran, peserta didik menjadi subjek dan objek dari kegiatan pembelajaran. Pendekatan pembelajaran itu mampu memberikan kebutuhan peserta didik aktif dan pendekatan itu juga dapat menarik peserta didik pasif supaya berubah menjadi aktif di pembelajaran. Pendekatan saintifik ialah pendekatan pembelajaran yang dilaksanakan dengan tahapan mengamati, menanya, mencoba, menalar, dan mengkomunikasikan. Metode penelitian ini menggunakan metode penelitian kualitatif. Subyek penelitiannya adalah Kepala Sekolah, Waka Kurikulum, dan Guru Pendidikan Agama Islam. Penelitian ini dilakukan di SMP Negeri I Beji. Tehnik pengumpulan data yang digunakan berupa observasi, wawancara dan dokumentasi. Sedangkan untuk tehnik analisis dan interpretasi data yang digunakan ini sesuai dengan konsep Mules and Hubermen yaitu reduksi data, penyajian data dan verifikasi data. Kesimpulan yang dapat diambil adalah implementasi K13 dengan pendekatan saintifik pada pelajaran PAI kelas VII di SMP Negeri I Beji yaitu memerlukan beberapa tahap yang dilakukan guru dan siswa di dalam kelas agar proses belajar dapat dikatakan berbasis ilmiah dan sesuai dengan kebutuhan kehidupan sehari-hari. Tahapan tersebut adalah mengamati, menanya, mengeksplorasi, mengasosiasi, dan mengkomunikasikan. Sedangkan untuk Hambatan dalam melaksakan pendekatan saintifik di SMPN 1 Beji pada pelajaran Pendidikan Agama Islam, yakni peserta didik masih malu untuk maju ke depan kelas dan Fasilitas pendukung yang masih terbatas.
\end{abstract}

Kata Kunci: Kurikulum 2013, Pendekatan saintifik, Pendidikan Agama Islam

Abstract: In the learning process, students become the subject and object of learning activities. The learning approach must be able to support the needs of active students and at the same time the approach must also be able to stimulate passive students to take part in learning. The scientific approach is a learning approach that is carried out by observing, asking, trying, reasoning, and communicating. This research method uses qualitative research methods. The research subjects are the Principal, Deputy Curriculum and Teachers of Islamic Religious Education. This research was conducted at SMP Negeri I Beji. Data collection techniques used were observation, interviews and documentation. Whereas the data analysis and interpretation techniques used are in accordance with the Mules and Hubermen concept of data reduction, data presentation and data verification. The conclusion that can be drawn is the implementation of K13 with a scientific approach in class VII PAI lessons at SMP Negeri I Beji, which requires several stages carried out by teachers and students in the classroom so that the learning process can be said to be scientifically based and in accordance with the needs of everyday life. These stages are observing, questioning, exploring, associating, and communicating. As for the obstacles in implementing the scientific approach at SMPN 1 Beji in Islamic Religious Education lessons, namely students are still embarrassed to go to the front of the class and the supporting facilities are still limited.

Keywords: 2013 curriculum, scientific approach, Islamic religious education 


\section{PENDAhuluan}

Pendidikan merupakan salah satu aspek yang paling urgen dalam kehidupan manusia, karena sejak masih dalam kandungan hingga meninggal manusia melakukan proses pendidikan. Peningkatan mutu pendidikan diperlukan untuk mengembangkan potensi diri peserta didik agar menjadi generasi penerus bangsa yang berkualitas dan mampu menerapkan ilmu yang diperolehnya sehingga bermanfaat bagi dirinya dan masyarakat. [1] Kurikulum 2013 disiapkan untuk mencetak generasi yang siap dalam menghadapi tantangan masa depan. Karena itu kurikulum disusun untuk mengantisipasi perkembangan masa depan. Acuan Kurikulum 2013 adalah mengarapkan agar peserta didik atau siswa memiliki kemampuan yang lebih baik dalam melakukan proses mengamati, menanya, mencoba, menalar dan mengkomunikasikan apa yang mereka peroleh atau mereka ketahui setelah menerima materi pelajaran. [2]

Dalam pendidikan terdapat proses pembelajaran yang menjadi kegiatan yang paling mendasar dan utama dalam suatu lembaga pendidikan. Dalam proses pembelajaran, peserta didik menjadi subjek dan objek dari kegiatan pembelajaran. [3] Setiap peserta didik mengalami proses pembelajaran yang beragam, kegeragaman dari siswa tersebut mempunyai ciri dari kepribadian yang dimiliki dari setiap individu dari siswa tersebut, guru harus menggunakan pendekatan pembelajaran secara efektif agar dapat meminimalisir dari keberagaman yang dimiliki siswa. Pendekatan pembelajaran itu mampu memberikan kebutuhan peserta didik aktif dan pendekatan itu juga dapat menarik peserta didik pasif supaya berubah menjadi aktif di pembelajaran. Sehingga dapat menciptakan kondisi pembelajaran yang menarik keaktifan siswa dalam pembelajaran PAI. [4]

Pendekatan saintifik ialah pendekatan pembelajaran yang dilaksanakan dengan tahapan mengamati, menanya, mencoba, menalar, dan mengkomunikasikan. Dari istilah tersebut dapat disimpulkan bahwa langkah-langkah yang perlu dilakukan dalam proses pembelajaran melalui pendekatan saintifik. [5] Pendekatan saintifik yang diterapkan di SMPN 1 Beji pada pelajaran PAI membuat peserta didiknya lebih bersemangat dalam mendalami pelajaran agama Islam. Selain itu peserta didik diarahkan agar bersikap akhlakul karimah terhadap guru dan teman sebayanya.Karena hal tersebut, SMPN 1 Beji sering mendapatkan juara dalam lomba-lomba keagamaan, diantaranya adalah mendapatkan juara 2 Musabaqah Tilawatil Qur'an tingkat kabupaten di Pasuruan.

\section{METODE}

Metode pada penelitian ini menggunakan penelitian lapangan yakni penelitian yang dilakukan dalam kancah kehidupan yang sebenarnya. Dilakukan dengan mengangkat data-data yang ada di lapangan berkaitan dengan model pembelajaran pada mata pelajaran pendidikan agama Islam dan budi pekerti. Jenis data penelitian ini menggunakan data kualitatif yakni penelitian dengan jenis data yang mempunyai sifat dekripsi serta data yang dihasilkan berdasarkan kondisi yang ada di lokasi. [6] Berikut ini penjelasan secara rinci tentang metode penelitian ini, antara lain:

\section{A. Subyek dan Lokasi}

Subyek penelitian dalam penelitian ini adalah Kepala Sekolah, Waka Kurikulum dan Guru Pendidikan Agama Islam. Penelitian ini dilakukan di SMPN 1 Beji.

\section{B. Jenis dan Sumber data}

Jenis data yang digunakan dalam penelitian ini merupakan penggunaan data kualitatif dan data kuantitatif, antara lain:

1. Data kualitatif yaitu data kualitatif yang disajikan dalam bentuk deskriptif, bukan menggunakan angka ataupun bilangan. Adapun data kualitatif pada penelitian ini meliputi Gambaran Umum di SMPN 1 Beji, Visi Dan Misi Sekolah, Keadaan Seluruh Siswa Dan Tenaga Pendidik, Implementasi pendekatan saintitifik pada Pendidikan Agama Islam Dalam Proses Pembelajaran.

2. Data kuantitatif merupakan data yang dipaparkan dalam bentuk angka dan bilangan sehingga dapat diukur dan dihitung. Data kuantitatif yang digunakan berupa jumlah seluruh siswa di SMPN 1 Beji, jumlah tenaga pendidik di SMPN 1 Beji.

Sedangkan Sumber data yang didapatkan peneliti berupa data primer dan data sekunder, ialah sebagai berikut :

1. Data primer merupakan sumber data yang bisa didapatkan melslui penelitian dari lokasi tersebut. Data primer yang didapatkan penulis berupa Rencana Proses Pembelajaran Pendidikan Agama Islam, Proses Pembelajaran Individu dan beberapa evaluasi pembelajaran.

2. Data sekunder merupakan sumber data yang didapatkan melalui orang lain atau melalui dokumen terkait masalah tersebut. [7]

\section{Teknik pengumpulan data}


Teknik pengumpulan data adalah cara yang digunakan oleh peneliti untuk mendapatkan data primer dalam suatu penelitian. [8] Teknik pengumpulan pada penelitian ini berupa teknik observasi, teknik wawancara, dan teknik dokumentasi.

\section{Teknik analisis dan interpretasi data}

Menurut pendapat dari Mules and Huberman dalam memaparkan analisis data dan interpretasi data tersebut memiliki beberapa tahapan diantaranya sebagai berikut :

1. Reduksi data berarti merangkum data yang diperoleh saat melakukan observasi, peneliti akan mendapatkan banyak data.

2. Penyajian data digunakan untuk menyajikan data dalam penelitian kualitatif adalah dengan teks yang bersifat naratif.

3. Verifikasi data (penarikan kesimpulan) yaitu memverifikasi data dan penarikan kesimpulan yang didapat di awal bersifat sementara tetapi apabila di dukung dengan bukti-bukti valid yang telah didapat dilapangan [9]

\section{III.HASIL DAN PEMBAHASAN}

\section{A. Implementasi pendekatan saintifik pada pelajaran Pendidikan Agama Islam}

Kurikulum 2013 menekankan pada aspek kognitif, afektif, dan psikomotorik dalam penerepannya. Sehingga kurikulum 2013 hadir dengan pendekatan saintifik untuk tercapainya kompetensi yang berimbang antara sikap, keterampilan, dan pengetahuan pada peserta didik. [10]

Di SMPN 1 Beji semua mata pelajaran yang ada pada kurikulum 2013 menggunakan pendekatan saintifik. Hal tersebut karena Kurikulum 2013 bertujuan untuk menyeimbangkan kompetensi siswa tidak hanya pada aspek kognitif saja akan tetapi pada aspek yang lain yakni afektif dan psikomotorik. Sehingga peserta didik tidak hanya pintar dalam teori saja namun juga pada prakteknya.

Sebelum melaksanakan pembelajaran pendidik melakukan perencanaan pembelajaran terlebih dahulu. Perencanaan merupakan tahap awal yang harus dilakukan setiap kali akan melakukan proses pembelajaran. untuk perencanaan proses pembelajaran di SMPN 1 Beji, para guru harus membuat RPP terlebih dahulu sebelum mengajar. Mereka membuat perangkat pembelajaran seperti RPP pada setiap awal semester.

Sedangkan dalam perencanaan implementasi pendekatan saintifik pada pelajaran PAI di SMPN 1 Beji disesuaikan dengan bab pelajaran yang akan dipelajari. Guru harus bisa menyesuaikan metode yang digunakan di dalam kelas, seperti ketika mempelajari bab mengenai sejarah Islam yang merupakan peristiwa yang sudah terjadi maka untuk tahapan mengeksplorasi pada pendekatan saintifik akan sulit diterapkan, sehingga hal tersebut bisa diganti dengan mengeksplorasi pelajaran yang terkandung dalam bab tersebut. Misalnya hikmah yang terkandung dalam sejarah kisah nabi Muhammad SAW dikaitkan dengan kejadian-kejadian yang dilakukan sehari-hari seperti sikap jujur, sabar, ikhlas dan lain-lain.

Di SMPN 1 Beji pada awal penerapan pendekatan saintifik siswa merasa bingung karena pembelajaran tidak dilakukan seperti biasanya. Namun hal bisa diatasi dengan membiasakan cara mengajar tersebut pada siswa. Pendekatan saintifik membutuhkan penyesuaian yang baik antara siswa dengan guru dan siswa dengan metode belajar di dalam kelas. Jika penyesuaian tersebut sudah bisa berjalan dengan baik maka guru dan siswa akan terbiasa dengan pendekatan saintifik sehingga proses pembelajaran bisa lancar.

\section{B. Hambatan dalam implementasi pendekatan saintifik pada pelajaran Pendidikan Agama Islam}

Dalam penerapan pendekatan saintifik terdapat beberapa hal yang bisa menghambat proses pembelajaran. Hal tersebut bisa terjadi karena penyesuaian pada kemampuan dan keadaan yang ada di sekolah. Di SMPN 1 Beji memiliki hambatan dalam melaksakan pendekatan saintifik pada pelajaran Pendidikan Agama Islam, yakni :

1. Peserta didik masih malu untuk maju ke depan kelas

Pendekatan saintifik bisa dikatakan efisien dan efektif dalam menunjang tingkat keberhasilan siswa dalam belajar. Namun terkadang peserta didik merasa malu untuk menyampaikan pendapatnya dikelas sehingga hal tersebut bisa menghambat proses pembelajaran dengan pendekatan saintifik. Sehingga guru PAI dituntut untuk bisa memotivasi peserta didik agar mau menyampaikan pendapatnya didepan teman-teman sekelasnya.

2. Fasilitas pendukung yang masih terbatas

Hambatan selanjutnya yang dirasakan oleh guru PAI dalam penerapan pendekatan saintifik adalah media dan fasilitas yang masih terbatas. Sehingga guru harus bergantian untuk menggunakannya. Hal tersebut membuat proses pembelajaran menggunakan pendekatan saintifik menjadi kurang maksimal karena guru memerlukan waktu yang lebih lama jika tidak menggunakan alat 
pendukung seperti LCD dalam pembelajarannya, sedangkan aspek yang harus diterima dan dipenuhi oleh peserta didik begitu banyak.

\section{KESIMPULAN}

. Pendekatan pembelajaran itu mampu memberikan kebutuhan peserta didik aktif dan pendekatan itu juga dapat menarik peserta didik pasif supaya berubah menjadi aktif di pembelajaran. Sehingga dapat menciptakan kondisi pembelajaran yang menarik keaktifan siswa dalam pembelajaran PAI. Pendekatan saintifik di SMPN 1 Beji pada pelajaran PAI membuat peserta didiknya lebih bersemangat dalam mendalami pelajaran agama Islam. Selain itu peserta didik diarahkan agar bersikap akhlakul karimah terhadap guru dan teman sebayanya

Di SMPN 1 Beji pada awal penerapan pendekatan saintifik siswa merasa bingung karena pembelajaran tidak dilakukan seperti biasanya. Namun hal bisa diatasi dengan membiasakan cara mengajar tersebut pada siswa. Pendekatan saintifik membutuhkan penyesuaian yang baik antara siswa dengan guru dan siswa dengan metode belajar di dalam kelas. Jika penyesuaian tersebut sudah bisa berjalan dengan baik maka guru dan siswa akan terbiasa dengan pendekatan saintifik sehingga proses pembelajaran bisa lancar.

Hambatan dalam melaksakan pendekatan saintifik di SMPN 1 Beji pada pelajaran Pendidikan Agama Islam, yakni peserta didik masih malu untuk maju ke depan kelas dan Fasilitas pendukung yang masih terbatas..

\section{UCAPAN TERIMA KASIH}

Dalam artikel ini kami ucapkan terima kasih kepada Allah SWT yang telah memberikan saya kesehatan sehingga kami bisa menyelesaikan artikel ini dengan sebaik mungkin. Yang kedua, kami ucapkan terima kasih kepada orang tua saya, ana najuwa dan sahabat-sahabat saya yang telah membantu dan mendukung saya. Untuk guru di SMPN 1 Beji yang telah bersedia untuk diperbolehkan melakukan penelitian dalam mengerjakan artikel ini sampai selesai.

\section{REFERENSI}

[1] Slameto, Belajar dan Faktor-Faktor yang Mempengaruhinya, Jakarta: Rineka Cipta, 2003.

[2] L. E. P. d. S. Amri, Panduan Memahami Kurikulum 2013, Jakarta: Prestasi Pustakarya, 2013.

Nurmadiah, "Kurikulum Pendidikan Agama Islam," Jurnal Al-Afkar, p. 48, 2014.

[4] R. A. Sani, Pembelajaran Saintifik untuk Implementasi Kurikulum 2013, Jakarta: PT. Bumi Aksara, 2014.

[5] M. Fadlillah, Implementasi Kurikulum 2013 Dalam Pembelajaran SD/MI, SMP/MTs, \& SMA/MA, Yogyakarta: Ar-Ruzz Media, 2014.

[6] Musfiqon, Paduan Lengkap Metodologi Penelitian Pendidikan, Jakarta: Prestasi Pustaka Publiser, 2012.

[7] Margono, Metodologi Penelitian Pendidikan, Jakarta: Rineka Cipta, 2014.

[8] B. d. Suwandi, Memahami Penelitian Kualitatif, Jakarta: Rineka Cipta, 2008.

[9] Sugiyono, Metode Penelitian Pendidikan Kualitatif, Kuantitatif daan R\&D, Bandung: Alfabeta, 2017.

[10] O. Hamalik, Kurikulum Dan Pembelajaran, Jakarta: Bumi Aksara, 2008. 
